\title{
品種の異なる米を素材とする米麺の品質評価
}

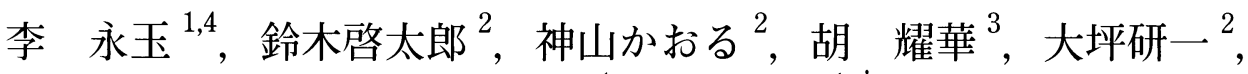 \\ 院多本華夫 ${ }^{1}$, 佐竹隆顕 ${ }^{1, \dagger}$ \\ ${ }^{1}$ 筑波大学 生命環境科学研究科, ${ }^{2}$ 農業 - 食品産業技術総合研究機構 食品総合研究所, \\ 3 西北農林科技大学, ${ }^{4}$ 中国農業大学,
}

\section{Quality Evaluation of Rice Noodles Made from Different Rice Varieties}

\author{
Yongyu $\mathrm{LI}^{1,4}$, Keitaro SUZUKI ${ }^{2}$, Kaoru KOHYAMA $^{2}$, Yaohua $\mathrm{HU}^{3}$, Kenichi OHTSUBO $^{2}$,
Keo INTABON ${ }^{1}$ and Takaaki SATAKE \\ ${ }^{1}$ Graduate School of Life and Environmental Sciences, University of tsukuba, Ten-nodai 1-1-1, \\ Tsukuba, Ibaraki 305-8572, Japan \\ ${ }^{2}$ National Food Research Institute, National Agriculture and Food Research Organization, \\ Kan-nondai 2-1-12, Tsukuba, Ibaraki 305-8642, Japan \\ ${ }^{3}$ Northwest A\&F University, Xinonglu 22, Yangling, Shaanxi 712100, China \\ ${ }^{4}$ China Agricultural University, Qinghuadonglu 17, Beijing 100083, China
}

In this study, rice noodles were made from a mixture of gelatinized dough and raw dough by using 6 varieties rice flours with different amylose content produced in Japan and China. Correlations between the physicochemical properties of rice flours and physical properties of cooked noodles as well as the correlations between the physical properties of cooked noodles and sensory evaluations were determined. Furthermore, the rice noodle qualities are discussed. Results showed that the amylose content was the main factor affecting the physical properties of cooked rice noodles. Amylose content was positively correlated to the maximum tensile stress, apparent elasticity and storage modulus of rice noodles, but negatively correlated to the loss tangent. Furthermore, all the rheological properties of rice noodles were significantly correlated to the setback of pasting properties obtained by RVA. The setback appears to be the main parameter for evaluating the physical properties of the rice noodles. The results of sensory evaluation of the rice noodles showed that the total score was positively correlated to the maximum tensile stress, maximum tensile strain, apparent elasticity and storage modulus of rice noodles, but negatively correlated to the loss tangent. The Yumetoiro variety form Japan and the Zhongzao22hao variety form China showed higher scores in sensory evaluation for producing rice noodles than the other varieties.

Keywords: rice noodle, amylose content, setback, physical property, sensory evaluation

\section{1. 緒言}

近年，食の多様化に伴い世界の様々な国より多種多 様な食品・食材が輸入される一方で, わが国の食料自 給率 (カロリーベース) は約 40\%程度まで減少している.

\footnotetext{
(受付 2007 年 4 月 27 日, 受理 2007 年 7 月 11 日)

1 ₹ 305-8572 茨城県つくば市天王台 1-1-1

2 ₹ 305-8642 茨城県つくば市観音台 2-1-12

3 个 712100 中国·陝西省楊凌西農路 22 号

4 广 100083 中国·北京清華東路 17 号

$\dagger$ Fax: 029-853-6130, E-mail: satake@sakura.cc.tsukuba.ac.jp
}

米は唯一自給可能な食材であるが消費量は漸減傾向に あり，農林水産省作物統計資料によると 1962 年の米消 費量は $118 \mathrm{~kg} /$ 人であったが，2005 年には $59.7 \mathrm{~kg} /$ 人に減少している.これに伴い米の過剩問題が生じ, 米の食用利用における高アミロース米, 色素米, 低ア レルゲン米などの新形質米を含めた需用拡大に向け新 たな加工品の開発・研究が課題となっている.

現在，わが国においては収穫米の約 $90 \%$ が米飯とし て食されて抢り，残りの約 $10 \%$ は加工用として消費さ れている. 米を粉砕し食品素材として利用することは, 従来から製菓など多くの分野でみられるが，主食に準 
ずる分野での利用は少ない。近年米の用途拡大を目的 とし米粉を素材としたパンやケーキが開発されている ものの，製麺素材への適用事例はわずかである. 麺類 は日本人の嗜好が強い主食の 1 つであり, 独特な食感 と食味をもつ米湎は今後広い普及が期待される. 従来, 米麺はアジア地域の伝統食品であり, 中国南方やタイ, ベトナムでは主食の 1 つとして昔から広く食されてい るが，米麺に関する研究は少なく製造は主に生産者の 経験に負うところが大きい．中国で作られている米麺 は高アミロースのインディカ米を原料とし，原料であ る米粉の一部を糊化した後エクストルーダなどにより 麺線化している。このような生地の部分的な糊化は, 中国やタイの伝統的な米麺製造において非常に重要な プロセスである.

日本における米湎の研究には 1979 年斉藤らがライス ヌードルを試作して以来, 米麺品質の向上を目的とし た研究に, 小麦粉澱粉, タピオカ澱粉など副材料の添 加による米麺品質の改良 [1,2] と生粉添加による食味の 改善 [3]，アクチナーゼ処理などによる食感の改善 [4] などがあり，一方，製造方法については，粳米を原料 とし小麦粉などを添加するとともに原料を部分的に糊 化させて麺線化している事例 [i] がある。また山田らは 米粉を蒸練し，さらに生米粉を添加して湎線化する方 法を報告している [1]. 喜多らはジャポニカ種のあきた こまちを原料とし，50\%の米粉懸濁液の内部温度が

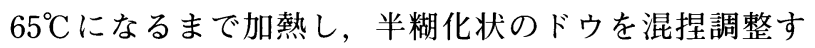
ることにより，パスタマシーンにかけられる硬さのド ウを調整する方法を報告した [2]. 以上，米湎の品質向 上や製造方法に関する先駆的な研究はなされているも のの, 国産の米品種と米麺物性, 官能評価などについ ての系統的な研究はなされていない.

著者らは小麦粉などの副材料を添加せず糊化生地と 生生地の混和による米麺調製方法を新たに提案し, 国 産の高アミロース米と中アミロース米を原料とし, 米 粉 $100 \%$ の高品質な米麺の開発を目指している.

本研究では, アミロース含量の異なる国産米 5 品種 と比較検討用としての中国産米 1 品種の計 6 品種の米 をそれぞれ原料として，糊化生地をつなぎとして用い 米粉 $100 \%$ の米湎を試作し, 米粉の理化学特性值と茹で 麺物性值および茹で麺物性值と官能評価值の相関関係 を求める一方，国産米と中国産の各品種の米をそれぞ れ原料とする米麺品質について比較検討を行った.

\section{2. 実験材料および方法}

\section{1 実験材料}

国産の高アミロース米の夢十色, ホシニシキ, ホシ ユタカと中アミロース米のきらら 397 , ベレパトナ (イ ンディカ種）および中国産の高アミロース米中早 22 号
(インディカ種）を原料とし，石臼式製粉機（宝田工業， M-200）を用いて製粉した。製粉した米粉は 60，83， 100，140，200，330 メッシュの篩を用い粒度別に篩分 けをし，140メッシュ（106〜150 $\mu \mathrm{m} ）$ の篩上物を本実 験材料とした。 また，市販されている手打ちうどん用 小麦粉（日清製粉）を比較のため実験材料に用いた.

\section{2 成分分析}

アミロース含量はヨード呈色比色法 [5] により測定し た.タンパク質含量は燃焼法 [6]により窒素量を測定し， 換算係数 5.95 を乗じてタンパク質含量とした.

\section{3 糊化特性}

米粉 $3 \mathrm{~g}$ (無水物換算) に $25 \mathrm{ml}$ の脱イオン水を加え, ラピッド・ビスコ・アナライザー（ニューポートサイ エンティフィック社製，3D 型）を用いて豊島ら [7]の 方法により測定した.

\section{2 生麺の試作方法}

米麺は糊化生地をつなぎとして用い，糊化生地と生 生地の混合によって米粉 $100 \%$ の米麺を試作した。米粉 $40 \mathrm{~g}$ (無水物換算) に蒸留水を加え，水分含量を $60 \%$ に調整し，オートクレーブ (平山製作所, HA-300P)

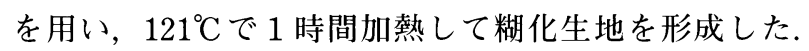
予備実験の結果よりすべての原料における製麺性を考 慮し, 生地に占める糊化米粉の割合は $10 \%$ とした。糊 化生地は石臼スクリュ式のミキサ（韓国 DONG-A OSCAR 社製，MA9100）を用い生生地と混合し，生地 に占める糊化米粉（無水物換算）割合 $10 \%$ の麺生地 150 $\mathrm{g}$ を形成した. 生地の水分含量は生生地に添加する蒸留 水によりすべて $40 \%$ に調整した. 米湎生地の温度は, 石臼スクリュ式ミキサで 3 分混合後, $44^{\circ} \mathrm{C} \sim 48^{\circ} \mathrm{C}$ まで 上昇している. 小麦粉は水分含量が $40 \%$ になように 調整し，同様な条件で石臼スクリュ式のミキサを用い， 麺生地を形成した。生地はパスタマシンで荒延べ 1 回, 圧延 2 回行い，最終的に厚さが約 $2 \mathrm{~mm}$ の麺帯を形成 した.

\section{3 生麺の茹で方法}

引張り試験用として $40 \mathrm{~mm} \times 90 \mathrm{~mm}$ の材料片, 動的 粘弾性測定用として $40 \mathrm{~mm} \times 40 \mathrm{~mm}$ の材料片を麺帯の 中心部からくり貫き, 室温 (約 $20^{\circ} \mathrm{C}$ ) で 3 時間静置後, 沸騰させた蒸留水 (麺重量の 50 倍量) で 2 分間茹でた. その後, $20^{\circ} \mathrm{C}$ の水道水の中で 1 分間冷却し, 表面水を 2 回キムワイプで軽く押さえながら取り除き, 茹で湎の 物性測定材料片とした.

\section{4 麺の色彩測定}

色彩色差計（ミノルタ株式会社, CR-200）を用い, 
生缅帯と茹で曙帯の $L^{*}, a^{*}, b^{*}$ 值を測定した． $L^{*}$ は明 度を表し， $a^{*}$ と $b^{*}$ は色度を表す。 $+a^{*}$ は赤方向， $-a^{*}$ は緑方向, $+b^{*}$ は黄方向, $-b^{*}$ は青方向を示す.

\section{5 茹で湎の物性測定}

\subsection{1 引張り試験}

レオメーター（レオテック，ADD-1002）を供試し， 専用の抜型で型抜きをした茹で缅帯試験片の引張り試 験を行い，破断応力 $\sigma$ (破断力 / 初期断面積, $\mathrm{kPa}$ ), 破 断ひずみ $\varepsilon$ (破断時の長さ一初期長さ／初期長さ，\%)， 見掛け弾性率 $E(\sigma / \varepsilon)$ などを求めた。測定は引張り速 度 $20 \mathrm{~cm} / \mathrm{min}$ の条件下で行った。

\subsection{2 動的粘弾性測定}

動的粘弾性の測定にはタイナミック・ストレス・レ オメーター（Rheometric Scientific USA，SR-5000）を 供試した．平行円板（ $\phi 25 \mathrm{~mm})$ 治具に合わせ，茹で湎 を直径 $25 \mathrm{~mm}$ の円盤状にくり貫き試験片とした。すべ

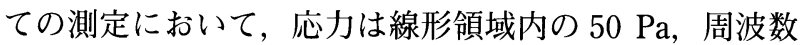
は $10 \mathrm{~Hz}$ ，測定温度は $20^{\circ} \mathrm{C}$ の条件下で貯蔵弾性率 $\left(G^{\prime}\right)$. 損失弾性率 $\left(G^{\prime \prime}\right)$ ·損失正接 $\left(\tan \delta=G^{\prime \prime} / G^{\prime}\right)$ を測定した.

\section{6 官能評価}

パスタマシンにて長さ約 $100 \mathrm{~mm}$ ，幅約 $2.2 \mathrm{~mm}$ に切 り出した米麺を沸騰させた蒸留水で 2 分間茹でた後, $20^{\circ} \mathrm{C}$ の水で 1 分間冷却し，さらにザル上で 1 分間水切 りし，直ちに官能評価に用いた。官能評価は，外観， 硬さ，弾力，なめらかさなどの項目について中国産の 中早 22 号の米湎を基準とし，評点法により行った。そ れぞれの項目について，基準麺より悪く感じる場合は マイナス (-) 方向に, 良好に感じる場合はプラス $(+)$ 方向に知覚した程度で 1 から 3 を選択する 7 段階評点 法で行った。 パネルは選抜された成人男女 8 人で構成 した.

\section{7 統計解析}

解析ソフトウエア（SPSS 13.0J）を用い相関係数を算
出し，その有意差を検定した。また，一元配置分散分 析により各測定値の有意差検定を行った.

\section{3. 実験結果および考察}

\section{1 米粉の成分分析}

Table 1 に示すように，本研究に供試した米粉のアミ ロース含量は $18.33 \sim 32.83 \%$ の範囲であり，夢十色と中 早 22 号のアミロース含量が最も高い值を示すものの, 両者には有意差が認められなかった。また米粉のタン パク質含量は 5.86〜 6.60\%の範囲であり，きらら 397 が 最も高い值を示した。一方，小麦粉のアミロース含量 は $10.15 \%$ であ，タンパク質含量は $100 \mathrm{~g}$ 当たり $9.0 \mathrm{~g}$ （表記）である。

\section{2 米粉の糊化特性}

RVA による各品種の米粉の糊化特性值を Table 2 に 示す．ベレパトナ，中早 22 号および夢十色は他の品種 に比べ Peak viscosity が高く膨潤しやすい特性を示した が，高アミロースの中早 22 号と夢十色の Breakdown は 166 RVU と 184 RVUでベレパトナの 308 RVUに比 ベ非常に低い值を示した。これはアミロースの膨潤し た澱粉粒の崩壊抑制作用 [8] が要因として考えられた. ホシニシキ，ホシュタカおよびきらら 397 の Peak viscosity は291〜314 RVU範囲で顕著な差異がみられ なかった。セットバックは 140〜270 RVU 範囲で夢十色

Table 1 Amylose and Protein content of rice flour.

\begin{tabular}{lcc}
\hline \multicolumn{1}{c}{ Varieties } & Amylose content (\%) & Protein content (\%) \\
\hline Yumetoiro & $32.28 \pm 0.35 \mathrm{e}$ & $5.86 \pm 0.03 \mathrm{a}$ \\
Hoshinishiki & $28.69 \pm 0.47 \mathrm{~d}$ & $6.02 \pm 0.05 \mathrm{~b}$ \\
Hoshiyutaka & $26.30 \pm 0.20 \mathrm{c}$ & $6.18 \pm 0.05 \mathrm{c}$ \\
Kirara397 & $20.56 \pm 0.36 \mathrm{~b}$ & $6.60 \pm 0.03 \mathrm{e}$ \\
Bellepatna & $18.33 \pm 0.06 \mathrm{a}$ & $6.33 \pm 0.09 \mathrm{~d}$ \\
Zhongzao22hao & $32.83 \pm 0.50 \mathrm{e}$ & $6.28 \pm 0.09 \mathrm{~d}$ \\
\hline
\end{tabular}

Mean of three replications \pm standard deviation.

Values with a different alphabetical letter differed significantly $(P<0.05)$

Table 2 RVA Pasting properties of rice flour.

\begin{tabular}{lcccccc}
\hline \multicolumn{1}{c}{ Varieties } & $\begin{array}{c}\text { Peak } \\
\text { viscosity } \\
\text { (RVU) }\end{array}$ & $\begin{array}{c}\text { Holding } \\
\text { viscosity } \\
\text { (RVU) }\end{array}$ & $\begin{array}{c}\text { Breakdown } \\
\text { (RVU) }\end{array}$ & $\begin{array}{c}\text { Setback } \\
\text { (RVU) }\end{array}$ & $\begin{array}{c}\text { Final } \\
\text { viscosity } \\
\text { (RVU) }\end{array}$ & $\begin{array}{c}\text { Pasting } \\
\text { gelatinization } \\
\text { temperature ( }\end{array}$ \\
\hline Yumetoiro & $447 \pm 3 \mathrm{~d}$ & $263 \pm 3 \mathrm{~d}$ & $184 \pm 1 \mathrm{~d}$ & $270 \pm 0 \mathrm{e}$ & $533 \pm 3 \mathrm{f}$ & $65.2 \pm 0.1 \mathrm{~b}$ \\
Hoshinishiki & $314 \pm 3 \mathrm{c}$ & $158 \pm 2 \mathrm{~b}$ & $156 \pm 2 \mathrm{~b}$ & $209 \pm 2 \mathrm{c}$ & $367 \pm 4 \mathrm{~d}$ & $65.8 \pm 0.2 \mathrm{~b}$ \\
Hoshiyutaka & $291 \pm 3 \mathrm{a}$ & $139 \pm 1 \mathrm{a}$ & $152 \pm 3 \mathrm{ab}$ & $210 \pm 1 \mathrm{c}$ & $349 \pm 2 \mathrm{c}$ & $64.8 \pm 0.2 \mathrm{a}$ \\
Kirara397 & $308 \pm 1 \mathrm{~b}$ & $157 \pm 3 \mathrm{~b}$ & $151 \pm 4 \mathrm{a}$ & $127 \pm 1 \mathrm{a}$ & $284 \pm 2 \mathrm{a}$ & $66.0 \pm 0.1 \mathrm{c}$ \\
Bellepatna & $485 \pm 3 \mathrm{f}$ & $177 \pm 1 \mathrm{c}$ & $308 \pm 4 \mathrm{e}$ & $140 \pm 1 \mathrm{~b}$ & $317 \pm 1 \mathrm{~b}$ & $80.1 \pm 0.0 \mathrm{e}$ \\
Zhongzao22hao & $461 \pm 7 \mathrm{e}$ & $295 \pm 5 \mathrm{e}$ & $166 \pm 2 \mathrm{c}$ & $226 \pm 6 \mathrm{~d}$ & $521 \pm 1 \mathrm{e}$ & $79.4 \pm 0.2 \mathrm{~d}$ \\
\hline
\end{tabular}

Mean of three replications \pm standard deviation.

Values with a different alphabetical letter differed significantly $(P<0.05)$. 
が最も高い值を示した. 降温過程での溶出アミロース のゲル形成による粘度上昇は，夢十色と中早 22 号が最 も著しく, Final viscosity も最も高い值を示した。一方， 中アミロース米のきらら 397 とベレパトナの Final viscosity は最も低い值を示した。糊化開始温度は中早 22 号とベレパトナが $79.4^{\circ} \mathrm{C}$ と $80.1^{\circ} \mathrm{C}$ で他の品種に比べ 高い值を示した。

\section{3 曙の色彩}

Table 3 に示すように, 米湎の $L^{*}, a^{*}, b^{*}$ は品種に より有意差が認められた. 生湎の $L^{*}$ は中早 22 号とホ シニシキが他の品種より有意に高い傾向を示し， $a^{*}$ は 夢十色, 中早 22 号, ホシニシキの生麺が他の品種に比 ベ有意に高い值を示した. $b^{*}$ はホシュタカの生麺が他 の品種より有意に高い傾向を示した．茹で麺の $L^{*}$ は中 早 22 号とホシニシキが他の品種に比べ有意に高い傾向 を示し,$a^{*}$ は夢十色の茹で麺が他の品種に比べ有意に 高い值を示した． $b^{*}$ は中早 22 号とホシユタカの茹で麺 が他の品種より有意に高い傾向を示した. 生麺および 茹で湎を問わず本研究で試作したすべての米麺は小麦 麺に比べ, $L^{*}$ と $a^{*}$ が有意に高く, $b^{*}$ は有意に低い傾向 を示した

\section{4 茹で麺の物性測定結果および理化学特性値との関係 3.4.1 引張り試験と理化学特性値}

Fig. 1 に示すように夢十色と中早 22 号の米粉より形 成された茹で麺の破断応力は有意差が認められず，他 の品種に比べ有意に高い值を示した $(p<0.05)$. 一方, 6 品種の米粉より形成された茹で麺の破断応力は米粉 のアミロース含量，七ットバック，最終粘度とそれぞ れ正の相関が認められた (Table 4).アミロースは冷却

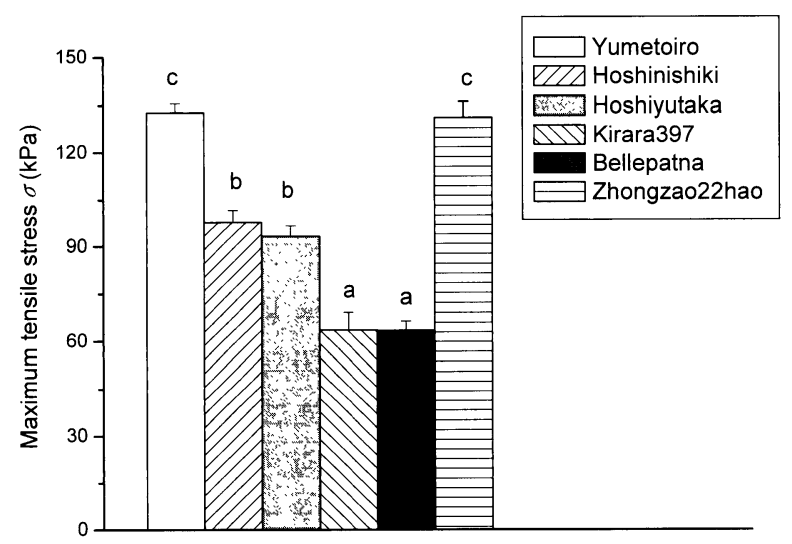

Fig. 1 Maximum tensile stress of rice noodles with different varieties.

Table 3 The color of raw and cooked noodle sheets.

\begin{tabular}{lccccccc}
\hline \multirow{2}{*}{ varieties } & \multicolumn{3}{c}{ Raw noodle sheets } & & \multicolumn{3}{c}{ Cooked noodle sheets } \\
\cline { 2 - 4 } \cline { 7 - 8 } & $L^{*}$ & $a^{*}$ & $b^{*}$ & & $L^{*}$ & $a^{*}$ & $b^{*}$ \\
\hline Yumetoiro & $84.05 \pm 0.13 \mathrm{c}$ & $-1.24 \pm 0.02 \mathrm{~d}$ & $6.27 \pm 0.13 \mathrm{a}$ & & $70.81 \pm 0.38 \mathrm{e}$ & $-1.65 \pm 0.03 \mathrm{e}$ & $3.66 \pm 0.23 \mathrm{~b}$ \\
Hoshinishiki & $86.09 \pm 0.06 \mathrm{~d}$ & $-1.21 \pm 0.05 \mathrm{~d}$ & $8.00 \pm 0.02 \mathrm{~d}$ & & $73.40 \pm 0.18 \mathrm{f}$ & $-1.84 \pm 0.06 \mathrm{~d}$ & $5.31 \pm 0.18 \mathrm{c}$ \\
Hoshiyutaka & $83.39 \pm 0.17 \mathrm{~b}$ & $-1.34 \pm 0.09 \mathrm{c}$ & $8.73 \pm 0.08 \mathrm{e}$ & & $69.06 \pm 0.85 \mathrm{~d}$ & $-1.98 \pm 0.04 \mathrm{c}$ & $5.64 \pm 0.21 \mathrm{~d}$ \\
Kirara397 & $83.85 \pm 0.07 \mathrm{~b}$ & $-1.31 \pm 0.02 \mathrm{c}$ & $7.10 \pm 0.16 \mathrm{~b}$ & & $67.01 \pm 0.55 \mathrm{~b}$ & $-1.91 \pm 0.04 \mathrm{c}$ & $2.94 \pm 0.26 \mathrm{a}$ \\
Bellepatna & $84.30 \pm 0.29 \mathrm{c}$ & $-1.41 \pm 0.05 \mathrm{~b}$ & $7.43 \pm 0.17 \mathrm{bc}$ & & $68.28 \pm 0.05 \mathrm{c}$ & $-2.27 \pm 0.08 \mathrm{~b}$ & $3.07 \pm 0.03 \mathrm{a}$ \\
Zhongzao22hao & $86.74 \pm 0.07 \mathrm{~d}$ & $-1.22 \pm 0.05 \mathrm{~d}$ & $7.5 \pm 0.10 \mathrm{c}$ & & $73.08 \pm 0.62 \mathrm{f}$ & $-1.84 \pm 0.07 \mathrm{~d}$ & $5.71 \pm 0.12 \mathrm{~d}$ \\
Wheat & $81.53 \pm 0.09 \mathrm{a}$ & $-2.86 \pm 0.12 \mathrm{a}$ & $15.47 \pm 0.25 \mathrm{f}$ & & $66.38 \pm 0.16 \mathrm{a}$ & $-3.12 \pm 0.03 \mathrm{a}$ & $8.88 \pm 0.24 \mathrm{e}$ \\
\hline
\end{tabular}

Mean of three replications \pm standard deviation.

Values with a different alphabetical letter differed significantly $(P<0.05)$

Table 4 Correlation coefficients between physico-chemical characteristics of rice flour and rheological properties of rice noodles.

\begin{tabular}{lcccccc}
\hline \multicolumn{1}{c}{ Indexes } & $\begin{array}{c}\text { Maximum } \\
\text { tensile stress }\end{array}$ & $\begin{array}{c}\text { Maximum } \\
\text { strain } \\
\varepsilon\end{array}$ & $\begin{array}{c}\text { Apparent } \\
\text { elasticity index } \\
E\end{array}$ & $\begin{array}{c}\text { Storage } \\
\text { modulus } \\
G\end{array}$ & $\begin{array}{c}\text { Loss } \\
\text { modulus } \\
G^{*}\end{array}$ & $\begin{array}{c}\text { Loss } \\
\text { tangent } \\
\tan \delta\end{array}$ \\
\hline Amylose content & $0.975^{* *}$ & 0.798 & $0.926^{* *}$ & $0.929^{* *}$ & -0.669 & $-0.929^{* *}$ \\
Protein content & -0.689 & $-0.895^{*}$ & -0.525 & $-0.830^{*}$ & 0.643 & 0.767 \\
Peak viscosity & 0.318 & -0.175 & 0.413 & -0.078 & 0.078 & 0.168 \\
Holding viscosity & 0.799 & 0.228 & $0.878^{*}$ & 0.422 & -0.312 & -0.390 \\
Breakdown & -0.383 & -0.496 & -0.328 & -0.561 & 0.445 & 0.657 \\
Setback & $0.942^{* *}$ & $0.858^{*}$ & $0.851^{*}$ & $0.919^{* *}$ & $-0.820^{*}$ & $-0.929^{* *}$ \\
Final viscosity & $0.967^{* *}$ & 0.576 & $0.968^{* *}$ & 0.725 & -0.609 & -0.711 \\
Pasting gelatinization & -0.035 & -0.543 & 0.141 & -0.391 & 0.494 & 0.461 \\
temperature & & & & & & \\
\hline
\end{tabular}

${ }^{* *}$, significant level $0.01 ;{ }^{*}$, significant level 0.05 
過程でアミロースのダブルヘリックスの結合部位が急 速に形成し，アミロース含量の高い米湎ほどアミロース により形成されるゲルのネットワーク構造が強固であ り，破断応力も高いと考えられた．また Fig. 2 に示すよ うに中早 22 号の茹で湎の破断ひずみは他の高アミロー ス品種（夢十色，ホシニシキ，ホシュタカ）に比べ有意 に低い值を示し $(p<0.05)$ ，破断ひずみはセットバック と正の相関，タンパク質含量と負の相関が認められた (Table 4). なお米粉中のプロラミンの除去により精米 粉の膨潤度が高まるとの報告 [9] やタンパク質の米飯の 粘性への影響に関する報告 [10] などもあり，タンパク 質は茹で麺物性に影響を与える主要な成分であると考 えられた. 一方, Fig. 3 に示すように，みかけ弾性率は 中早 22 号の茹で麺が最も大きい值を示し，米粉のアミ ロース含量, 最低粘度, セットバック, 最終粘度と正の 相関が認められた（Table 4). 小麦麺はレオメーターの 引張り許容変位を越える変形を示したため測定ができ ず，米湎とは物性が大きく異なる麺であると考えられた．

\subsection{2 動的粘弾性と理化学特性値}

Fig. 4 に示すように, 高アミロースの夢十色, ホシニ

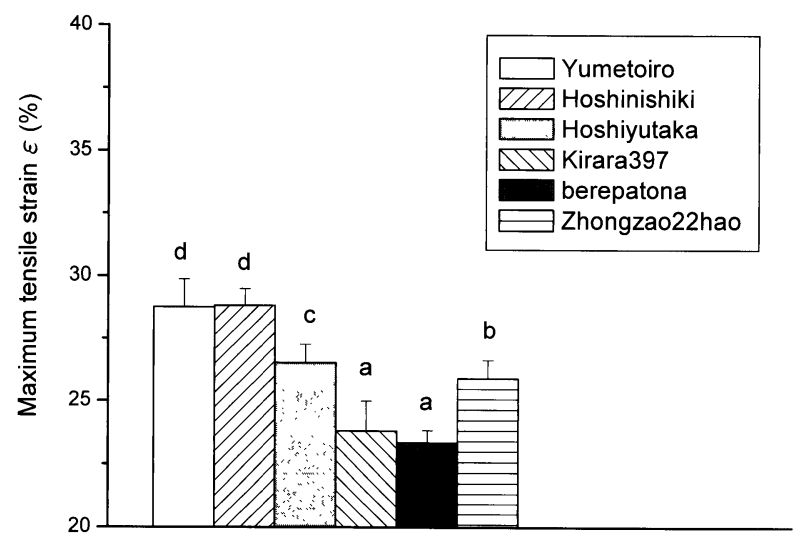

Fig. 2 Maximum tensile strain of rice noodles with different varieties.

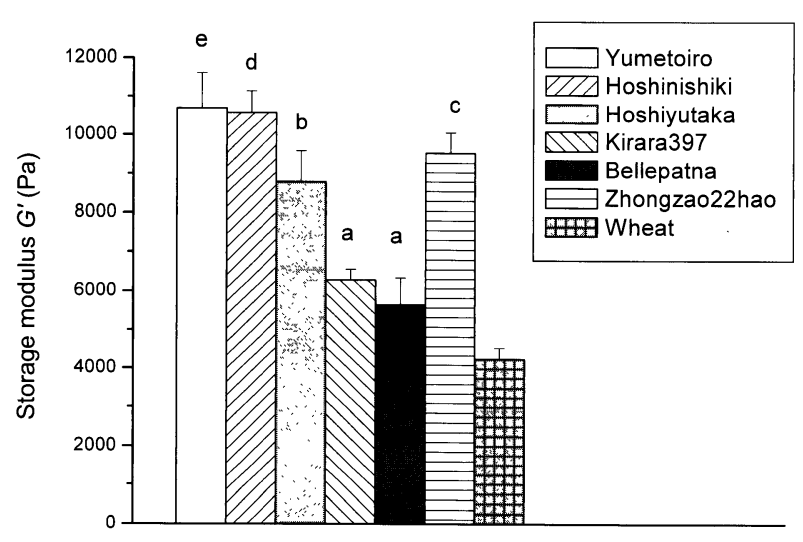

Fig. 4 Storage modulus $\left(G^{\prime}\right)$ of rice noodles.
シキ, ホシュタカ, 中早 22 号の茹で麺の貯蔵弾性率は, 中アミロースのきらら 397 とベレパトナに比べ有意に高 い傾向を示し，夢十色とホシニシキの茹で麺の貯蔵弾性 率が中早 22 号より有意に高い傾向を示した $(p<0.05)$. 弾性要素を示す貯蔵弾性率はアミロース含量, セット バックと正の相関，タンパク質含量と負の相関が認めら れた (Table 4). また Fig. 5 に示すように高アミロース の夢十色，ホシニシキ, ホシュタカ, 中早 22 号の茹で 麺の損失弾性率は，中アミロースのきらら 397 とベレパ トナに比べ有意に低い傾向を示し, 夢十色とホシュタカ の茹で麺が中早 22 号より有意に低い值を示した $(p<$ 0.05). 粘性要素を示す損失弾性率はセットバックと負 の相関が認められた (Table 4). 一方，Fig. 6 に示すよ うに高アミロースの夢十色，ホシニシキ，ホシュタカ, 中早 22 号の茹で麺の損失正接 $\left(\tan \delta=G^{\prime \prime} / G^{\prime}\right)$ は，中 アミロースのきらら 397 とベレパトナに比べ有意に低い 值を示し，高アミロースの夢十色の茹で麺の損失正接が 他の品種に比べ有意に低い傾向を示した，損失正接はア ミロース含量，七ットバックと負の相関が認められた (Table 4). なお，すべての茹で米麺の貯蔵弾性率は小 麦麺に比べ高い值を示したものの，小麦麺の貯蔵弾性率

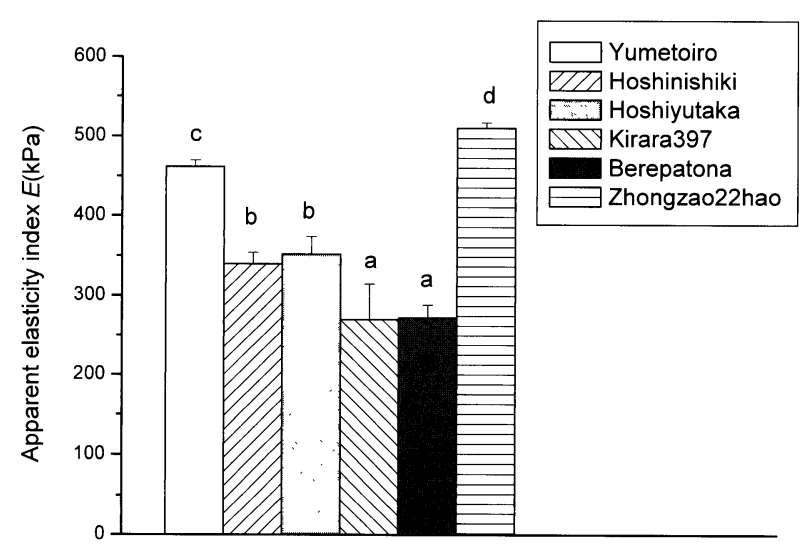

Fig. 3 Apparent elasticity index of rice noodles with different varieties.

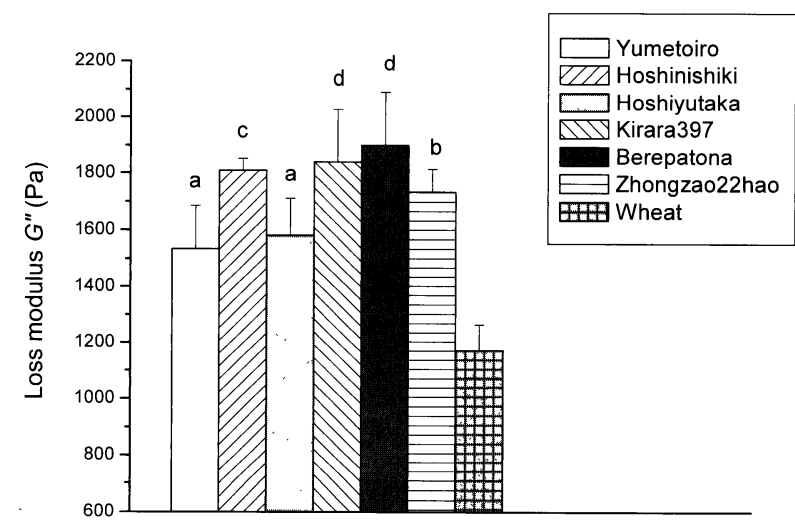

Fig. 5 Loss modulus $\left(G^{\prime \prime}\right)$ of rice noodles. 


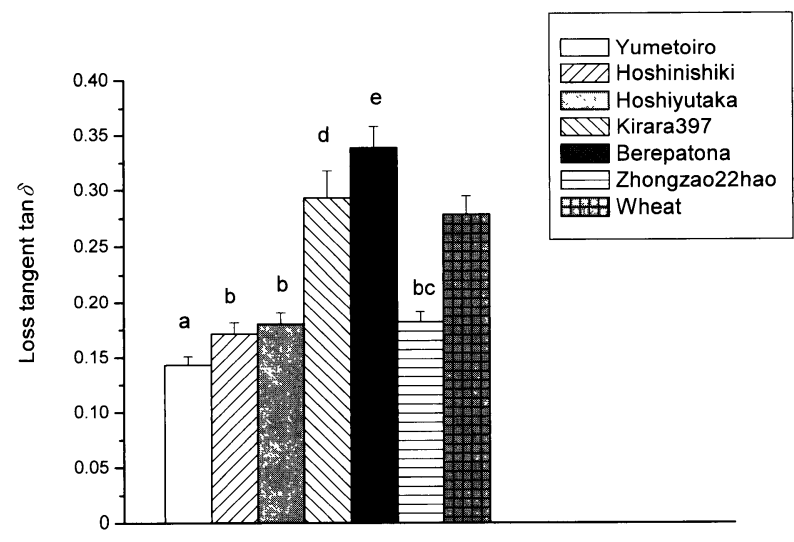

Fig. 6 Loss tangent $(\tan \delta)$ of rice noodles.

は中アミロースのきらら 397 とベレパトナの茹で湎に 近い值を示し (Fig. 4), 損失弾性率はきらら 397 とべ レパトナと大きく異なる值を示した（Fig. 5) ことから， 米缅は小麦湎とは大きく異なる特性を示すと考えられ た。

米飯の動的粘弾性に関する既往の研究に, アミロー ス含量の増加により米飯の貯蔵弾性率は増加する傾向 がある一方, $\tan \delta$ は低下する傾向が認められるとの報 告 [11] があるが，本研究に打いても米粉のアミロース 含量が茹で麺の貯蔵弾性率と正の相関, $\tan \delta$ と負の相 関が認められた。 また，ブレークダウンは米飯の貯蔵 弾性率と負の相関が認められるとの報告 [12] がある一 方, アミロース含量とセットバックは小麦麺のテクス チャに影響し，アミロース含量とセットバックが低い ほど，麺の貯蔵弾性率も低下する傾向が認められたと の報告 [13] がある. 本研究ではブレークダウンと茹で 麺の物性值との相関が認められず，Table 4 に示すよう にセットバックとすべての茹で麺物性值との相関が認 められ, 茹で湎物性においてセットバックは最も重要 な指標であると考えられた。

\section{5 官能評価結果および物性測定値との関係}

中国産の高アミロース米中早 22 号の茹で湎を基準と して行った官能評価の結果を Fig. 7 に示す. 茹で麺の外 観は同図に示すように中アミロースのきらら 397 とべレ パトナおよび高アミロースのホシュタカの茹で麺が基準 麺より評点が有意に低い傾向を示した. 茹で麺の色彩測 定結果（Table 3）から，きらら 397 とベレパトナおよ びホシユタカの茹で麺が他の品種に比べ明度が低く暗い ことが明らかであり，それらの外観評点も低かったと考 えられた. また, 中アミロースのきらら 397 とベレパト ナの茹で湎は高アミロースの茹で麺に比べ, 麺線同士の 付着性が強く, 外観評点が最も低かったと推察された. 茹で麺の弾力は Fig. 7 に示すように国産の高アミロース 米の夢十色, ホシニシキ, ホシュタカの茹で麺が基準
麺より評点が高く，ホシユタカと夢十色の茹で麺は基 準麺と有意差が認められた. 一方, 高アミロースの夢 十色とホシニシキの硬さは基準麺と有意差が認められ なかったが, 高アミロースのホシュタカは基準麺より 有意に低い值を示した。 また，夢十色の茹で湎のなめ らかさは, Fig. 7 に示すように基準麺に比べ高い評点を 示したが有意差は認められなかった．他の品種の茹で 麺のなめらかさは基準麺より評点が有意に低い值を示 した．茹で缅の総合評価は夢十色の茹で麺が基準湎よ り有意に高い值を示す一方，他の品種の茹で麺は基準 麺より評点が有意に低い值を示した.

また，米湎は麺線の太さによりその嗜好性が大きく 左右されるとの報告 [14] や，細い米麺ほど硬い物性の ものが米麺の特性に合い, 麺線が細い米麺が有意に好 まれるとの報告がある [15]. 本研究で用いた麺線は太 さが皆一定であるものの, 官能評価に用いた茹で湎は 比較的細い麺線であり, 夢十色と中早 22 号の茹で麺が 官能評価の硬さの評点において比較的高い傾向を示す 一方, 総合評価も他の品種に比べ高い傾向を示した. 即ち，国産の夢十色は既に米湎素材として中国におい て実績のある中早 22 号に劣らず，米麺素材として他の 国産米に比べて優れていることが明らかとなった。ま た，本研究で中アミロースのきらら 397 とベレパトナ の茹で湎は各項目の評点が低く, 中アミロースの米粉 $100 \%$ にる米麺の品質は高くないものと推察された.

一方, Table 5 に示すように茹で麺の外観は最大ひず み・貯蔵弾性率と正の相関，損失正接と負の相関が認 められた．前述（Table 4) のようにアミロース含量と セットバックは茹で麺物性に影響を与える主要な指標 であり，アミロース含量が高くセットバックが高い米 粉より試作した茹で麺は，糊化澱粉中のアミロースに より形成されるゲルのネットワーク構造が強固であり, 湎線同士の付着性も低く外観上の評価も高いものと推 察された.さらに, 茹で湎の弾力と硬さは Table 5 に示

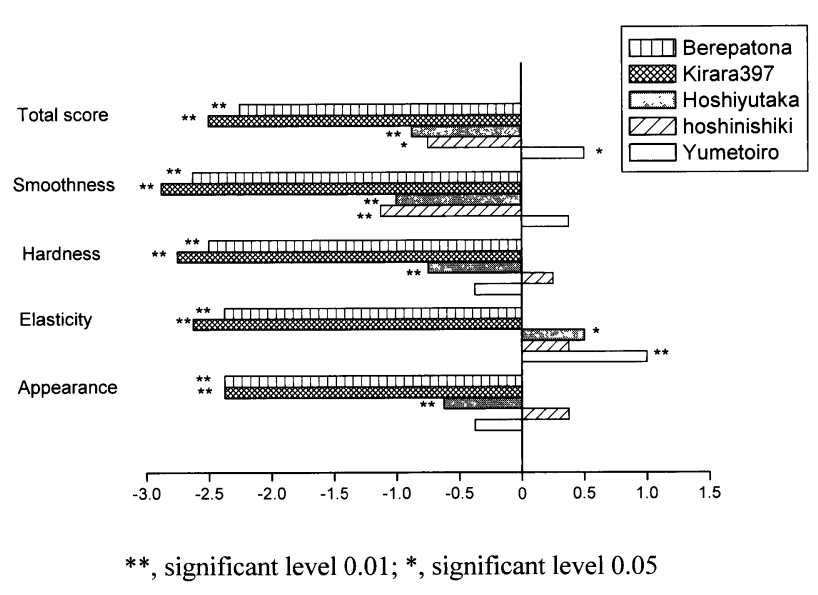

Fig. 7 Sensory qualities of cooked rice noodles. 
Table 5 Correlation coefficients between noodle quality and rheological properties.

\begin{tabular}{|c|c|c|c|c|c|c|}
\hline Indexes & $\begin{array}{r}\text { Maximum } \\
\text { tensile stress } \\
\sigma \\
\end{array}$ & $\begin{array}{l}\text { Maximum } \\
\text { strain } \\
\varepsilon\end{array}$ & $\begin{array}{c}\text { Apparent } \\
\text { elasticity index } \\
E\end{array}$ & $\begin{array}{c}\text { Storage } \\
\text { modulus } \\
G^{\prime}\end{array}$ & $\begin{array}{c}\text { Loss } \\
\text { modulus } \\
G ”\end{array}$ & $\begin{array}{c}\text { Loss } \\
\text { tangent } \\
\tan \delta\end{array}$ \\
\hline Appearance & 0.809 & $0.874^{*}$ & 0.715 & $0.952^{* *}$ & -0.517 & $-0.919^{* *}$ \\
\hline Springness & $0.838^{*}$ & $0.911^{*}$ & 0.721 & $0.944^{* *}$ & -0.803 & $-0.967^{* *}$ \\
\hline Hardness & $0.835^{*}$ & $0.868^{*}$ & 0.747 & $0.950^{* *}$ & -0.533 & $-0.915^{*}$ \\
\hline Smoothness & $0.985^{* *}$ & 0.773 & $0.936^{* *}$ & $0.886^{*}$ & -0.775 & $-0.903^{*}$ \\
\hline Total score & $0.980 * *$ & $0.814^{*}$ & $0.915^{*}$ & $0.912^{*}$ & -0.760 & $-0.914^{*}$ \\
\hline
\end{tabular}

** , significant level $0.01 ;{ }^{*}$, significant level 0.05

すように最大応力, 最大ひずみ, 貯蔵弾性率と正の相関, 損失正切と負の相関を示す一方；茹で麺のなめらかさ は最大応力， みかけ弾性率，貯蔵弾性率と正の相関， 損失正切と負の相関を示した。茹で悳の総合評点は最 大応力, 最大ひずみ, 及かけ弾性率, 貯蔵弾性率と正 の相関, 損失正切と負の相関が認められた。したがって, 米麺に適する素材の選択に当たってはこれらの物性値 が素材選択の指標の一端になるものと考えられる.

\section{4. 結 論}

本研究では，アミロース含量の異なる国産と中国産 の 6 品種の米をそれぞれ原料として, 副材料を添加せ ずに米粉 $100 \%$ 米麺を試作し，米粉の理化学特性值と 茹で麺物性値および茹で麺物性值と官能評価結果の相 関関係を求める一方，茹で麺品質の比較検討を行い以 下の知見を得た。

(1) 米粉のアミロース含量は茹で麺物性に大きな影響を 与える因子であり, 茹で湎の破断応力, 及かけ弾性率, 貯蔵弾性率と正の相関，損失正接と負の相関が認めら れた. とくに，米粉の RVAの糊化特性值セットバック は茹で麺の全ての物性測定值と相関が認められ，茹で 湎物性に対して最も重要な指標であることが明らかに なった。

(2) 米缅の $L^{*} \cdot a^{*} \cdot b^{*}$ は米品種により有意差が認められ た. 中国産の中早 22 号の茹で麺の $L^{*}$ と $b^{*}$ は最も高い 值を示し, $a^{*}$ は日本産の夢十色の茹で麺が最も高い值 を示した。本研究で試作したすべての米湎は小麦湎に 比べ, $L^{*}$ と $a^{*}$ が有意に高く $b^{*}$ が有意に低い值を示し, 米麺は小麦麺に比べ明度が高い一方, 緑色成分と黄色 成分は低い傾向を示すことが明らかになった。

(3) 茹で缅の官能評価の総合評点は最大応力, 最大ひず み, みかけ弾性率, 貯蔵弾性率と正の相関, 損失正接 と負の相関が認められたことから，米麺に適する素材 の選択に当たってはこれらの物性值が素材選択の指標 の一端になるものと考えられた. また, 官能評価の結果, 高アミロース米の一種である夢十色は, すでに米湎素 材として中国において実績のある中早 22 号に劣らず他
の国産米に比べ米麺素材として好ましいと考えられた.

\section{5. 参 考 文 献}

[1] 山田進, 秋本隆司; ライスヌードルの物性改善. 新潟県食 品研究所研究報告, 25, 41-44 (1990).

[2] 長尾慶子, 喜多記子; ジャポニカ種米粉湎の調整とその力 学特性ならびに官能評価の検討. 農業機械学会誌, 69 , 17-21 (2007).

[3] 石井修一, 江川和徳, 斉藤昭三 ; ライス，ヌードルの製造 条件について。新潟県食品研究所研究報告， 17，33-36 (1980).

[4] 対崎岩夫, 小野寺隆, 伊藤啓夫 ; 新形質米の高度利用化の 研究 新形質米の他用途性の開発. 宮城県工業技術セン ター, 27, 64-68 (1996).

[5] B. O. JULIANO; A simplified assay for milled-rice amylase. Cereal science Today, 16, 334-340 (1971).

[6] American Association of Cereal Chemists. Approved Methods of the AACC, Method 46-30, Final approval November 8, 1995, reapproval November 3, 1999.

[7] 豊島英親, 岡留博司, 大坪研一ら ; ラピット・ビスコ・ アナライザーによる米粉粘度特性の微量迅速測定方法に 関する共同試験. 日本食品科学工学会誌，44，579-584 (1997).

[8] A. M. Hermansson, K. Svegmark; Developments in the understanding of starch functionality. Trends in Food Sci \& Tech, 7, 345-353 (1996).

[9] 平俊雄, 庄司一郎 ; たんぱく質の除去が精米粉の膨潤度 と溶解度に与える影響. 日本食品科学工学会誌, 47, 638-641 (2000).

[10] Hamaker, B. R., Griffin, V. K.; Changing the viscoelastic properties of cooked rice through protein disruption. Cereal Chemistry, 67, 261-264 (1990).

[11] 乙部和紀, 内藤成弘, 杉山純一, 菊池祐二; 米飯の動的粘 弾性と官能評価. 日本食品科学工学会誌, 42, 12-19 (1995).

[12] 吉井洋一, 乙部和紀, 杉山純一; 動的粘弾性測定による 米飯の品種特性の解明. 日本食品科学工学会誌, $\mathbf{4 0}$, 236-243 (1993). 
[13] 谷藤健，金子成延，松倉潮; 小麦のデンプンおよびグルテ ンの特性がゆでめんのテクスチャーに及ぼす影響. 日本 食品科学工学会誌, 50, 333-338 (2003).

[14] 柴田茂久, 今井徹, 稲荷佐登美; 乾めんの貯藏に関する研 究. 日本食品工学会誌, 25, 57-65 (1978).

[15] 穴戸功一, 江川和徳, 諸橋敬子, 泉田又蔵, 山田進 ; 酵 素処理米粉を利用した製䁉. 新潟県食品研究所研究報告, 28, 1-6 (1993).

\section{引用 URL}

[i] http://www.okomeramen.co.jp/manufacture.html (2006.5)

\section{要 旨}

国産と中国産のアミロース含量の異なる 6 品種の米 をそれぞれ原料とし，糊化生地と生生地の混和により 米粉 $100 \%$ の米湎を試作した. 米粉の理化学特性值と茹 で缅物性値および茹で麺物性值と官能評価の相関関係 を求める一方，茹で缅品質の比較検討を行った．その 結果，アミロース含量は茹で麺物性に大きな影響を与 える要素であり, 茹で麺の破断応力・見掛け弾性率・ 貯蔵弾性率と正の相関，損失正接と負の相関が認めら れた. また，米粉の RVAの糊化特性值セットバックは 茹で湎の全ての物性值との相関が認められ, 茹で麺物 性において最も重要な指標であることが明らかになっ た. 一方, 官能評価の総合評点は茹で麺の破断応力, 破断ひずみ, 見掛け弾性率, 貯蔵弾性率と正の相関, 損失正接と負の相関が認められるとともに，国産の夢 十色は中国産の中早 22 号に劣らず，米麺素材として他 の国産米に比べて優れていることが明らかとなった. 